\title{
Chapter 22 \\ Experience and Lessons from Alien and Invasive Animal Control Projects in South Africa
}

\author{
Sarah J. Davies D, Martine S. Jordaan (D, Minette Karsten (D, \\ John S. Terblanche $\mathbb{D}$, Andrew A. Turner $\mathbb{D}$, Nicola J. van Wilgen $\mathbb{D}$, \\ Ruan Veldtman (D, Tsungai A. Zengeya (D), and John Measey
}

\footnotetext{
S. J. Davies $(\varangle) \cdot$ J. Measey

Centre for Invasion Biology, Department of Botany and Zoology, Stellenbosch University, Stellenbosch, South Africa

e-mail: sdavies@sun.ac.za
}

\section{S. Jordaan}

CapeNature Biodiversity Capabilities Directorate, Cape Town, South Africa

Centre for Invasion Biology, South African Institute for Aquatic Biodiversity, Makhanda, South Africa

M. Karsten · J. S. Terblanche

Centre for Invasion Biology, Department of Conservation Ecology and Entomology,

Stellenbosch University, Stellenbosch, South Africa
A. A. Turner
CapeNature Biodiversity Capabilities Directorate, Cape Town, South Africa

Department of Biodiversity and Conservation Biology, University of the Western Cape,

Bellville, Cape Town, South Africa

N. J. van Wilgen

Centre for Invasion Biology, Department of Botany and Zoology, Stellenbosch University, Stellenbosch, South Africa

Cape Research Centre, South African National Parks, Cape Town, South Africa

R. Veldtman

Department of Conservation Ecology and Entomology, Stellenbosch University, Stellenbosch, South Africa

South African National Biodiversity Institute, Kirstenbosch Research Centre, Cape Town, South Africa

T. A. Zengeya

South African National Biodiversity Institute, Kirstenbosch Research Centre, Cape Town, South Africa

Centre for Invasion Biology, Department of Zoology and Entomology, University of Pretoria, Pretoria, South Africa 


\begin{abstract}
South Africa has a rich history of managing invasive alien animal populations. This chapter explores examples of animal control projects, their resourcing and degree of success or failure. Out of 1023 alien animal species present in South Africa, 80 are designated for compulsory control or eradication in national legislation, and 24 are currently being controlled with the aim of eradication or containment. Only two species have been successfully eradicated from mainland SA and its near-shore islands: Otala punctata (the Freckled Edible Snail) and Trogoderma granarium (the Khapra Beetle). These two projects took place in the late 1980s and early 1990s, and were rapid responses by small groups of role players to small infestations. In contrast, most current projects are larger, involving complex stakeholder management and considerable technical complexity. Three further invertebrate species are currently controlled through integrated pest management (Bactrocera dorsalis, the Oriental Fruit Fly) or nest removal (Vespula germanica, the German Wasp and Polistes dominula, the European Paper Wasp). No marine species are currently subject to control. Among vertebrates, 12 freshwater fish species have been controlled in localised areas, according to their specific listing in legislation and protected area management priorities; two amphibian, two bird and five mammal species are currently subject to control using a wide variety of techniques. Inter-institutional working groups have played a significant role in promoting the success of invasive alien species management in South Africa. Three working groups are actively addressing new and existing invasions, and promoting awareness and cooperation among a wide range of organisations, as well as recording the experience and learning of these groups.
\end{abstract}

\title{
22.1 Introduction
}

On average 50-100 alien animal taxa, including feral domestic animals, have established naturalised or invasive populations per quarter degree square in South Africa (Picker and Griffiths 2017). This tally belies a range of invasion levels of different taxa from very low in amphibians and marine fish, to very high in freshwater fish (van Rensburg et al. 2011). Vertebrates make up 30\% of introduced animal species in South Africa $(n=309$; Picker and Griffiths 2017), while insects, crustacea, annelids, molluscs and arachnids make up the remaining 70\% (713 species; van Wilgen and Wilson 2018). Among vertebrates, freshwater fish species (17) and mammals (13) are most often introduced, while fewer birds (9) and reptiles (1) and no amphibian species have been introduced from outside the country. Consequently, there have been relatively few fully-fledged control projects undertaken, but a wide range of methods have been used, ranging from manual capture of Freckled Edible Snails (Otala punctata) and European Shore Crabs (Carcinus maenas) to the use of anaesthetic for Mallards (Anas platyrhynchos), toxic baits for House Crows (Corvus splendens) and piscicide such as rotenone for several fish species.

In South Africa, the management of alien and invasive species is guided by the Alien \& Invasive Species Regulations (RSA 2014) of the National Environmental 
Management: Biodiversity Act (Act 10 of 2004) (referred to as NEM:BA). The intent of the regulations is to reduce the risk of importing potentially invasive or harmful alien species, reduce the number of alien species becoming invasive, and limit the extent and impact of invasions (see van Wilgen et al. 2020, Chap. 1, Box 1.1).

The regulations prohibit the importation of alien species that are known to be invasive elsewhere in the world but are not yet in the country (prohibited species). Alien species that are already present but not widespread in the country can be targeted for eradication (Category 1a). In cases where invasive species are widespread the most practical option is often to contain further spread (Category 1b). The regulations have a provision for utilisation of listed alien species that provide benefits to human wellbeing, albeit with some strict conditions (Categories 2 and 3).

Current role-players in invasive and alien animal control programmes include national agencies such as South African National Parks (SANParks), provincial nature conservation agencies such as CapeNature (Western Cape Province), local authorities such as eThekwini Municipality (Durban) and a range of consultants and NGOs (e.g. Society for the Prevention of Cruelty to Animals). Research and higher education organisations such as universities, national research facilities and institutes provide information, best practice and expertise for monitoring alien and invasive species. A range of inter-institutional working groups on invasive taxa have been developed in South Africa, and these play a crucial role in advising government on management options and best practice and broadening participation and information flow. Invasive alien animal working groups in the Western Cape and KwaZulu-Natal (KZN) bring together role players to discuss priorities and species requiring control and to advise the responsible institutions on methods. Recently, a Marine Alien and Invasive Species Working Group has been constituted at a national level to advise on prioritisation of management of marine invasive species. This group will complement the work done by the terrestrial Western Cape and KZN working groups.

This chapter addresses the animal control operations of which we are aware, arranged by habitat and taxonomic groups. We describe the control projects that have been attempted in South Africa (except for offshore islands, see Greve et al. 2020, Chap. 8), including the methods used, when the operation started, how long the operation lasted, by whom it was undertaken, and what funding/resources were used. Where possible, we note the breadth of the stakeholder base, the relative success and current status of the programme. Biological control operations are included hypothetically, but none have yet been applied to animals on a large scale. The final section of the chapter addresses the learning points that have emerged and which could be used to maximise the effectiveness of alien and invasive animal management in South Africa. 


\subsection{Freshwater Invertebrates}

\subsubsection{Procambarus clarkii (Red Swamp Crayfish)}

While 22 alien freshwater invertebrates have been documented in South Africa (Picker and Griffiths 2017), and several, particularly snails, are known to have impacts (e.g. see de Kock and Wolmarans 2008), there is no documentation on control of these species, aside from the Red Swamp Crayfish (see also Chap. 6).

Procambarus clarkii (the Red Swamp Crayfish) is native to North America but has been introduced in several African countries, including South Africa (see Weyl et al. 2020, Chap. 6). This species is important in aquaculture and has invaded parts of Africa via this pathway. By replacing native crab and snail populations, and consuming aquatic vegetation, red swamp crayfish exert trophic impacts and may also have structural impacts in rivers (Jackson et al. 2016). In 1988 this species was found in one or more dams on a farm in Mpumalanga, and in 1994 a control operation was undertaken by the provincial nature conservation authority to remove all $P$. clarkii from one dam, which was partially drained, and all crayfish were removed by hand or using dip-nets (Nunes et al. 2017). Unfortunately, this operation was poorly documented and monitoring data are not available. In a follow-up survey in 2015 and 2016, Nunes et al. (2017) used sweep nets, electrofishing and trapping, and established that $P$. clarkii was still present. No further follow ups have been conducted since 2016. Procambarus clarkii is listed as a prohibited species in NEM: BA (RSA 2014) but its presence in the country implies that its listing should be changed to Category $1 \mathrm{a}$ and that the species should be a target for national eradication (Table 22.1).

\subsection{Marine Invertebrates}

Information on introduced marine species has grown rapidly since the 1990s, when 15 introduced marine organisms were recognised (Griffiths et al. 1992); in 2011 a comprehensive review and survey identified 85 introduced and 39 cryptogenic marine organisms (Mead et al. 2011a, b). Currently, 95 introduced marine invertebrates are present in South Africa (Robinson et al. 2020, Chap. 9), although only one species (described below) has been subjected to control. Recognising the need for more research and management options for marine species, the Marine Alien and Invasive Species Working Group has recently been formed to advise on prioritisation of management of marine invasive species at a national level. 


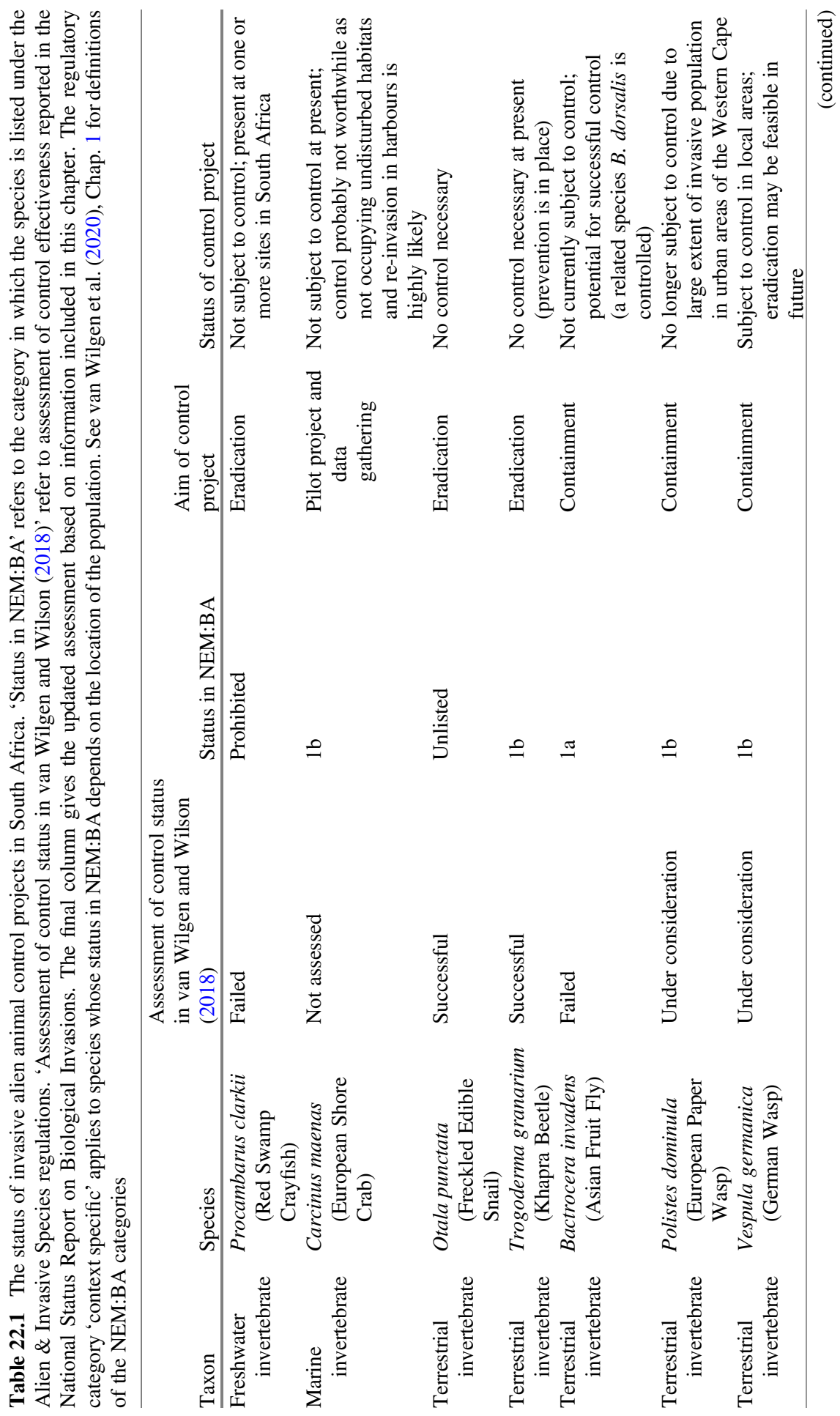




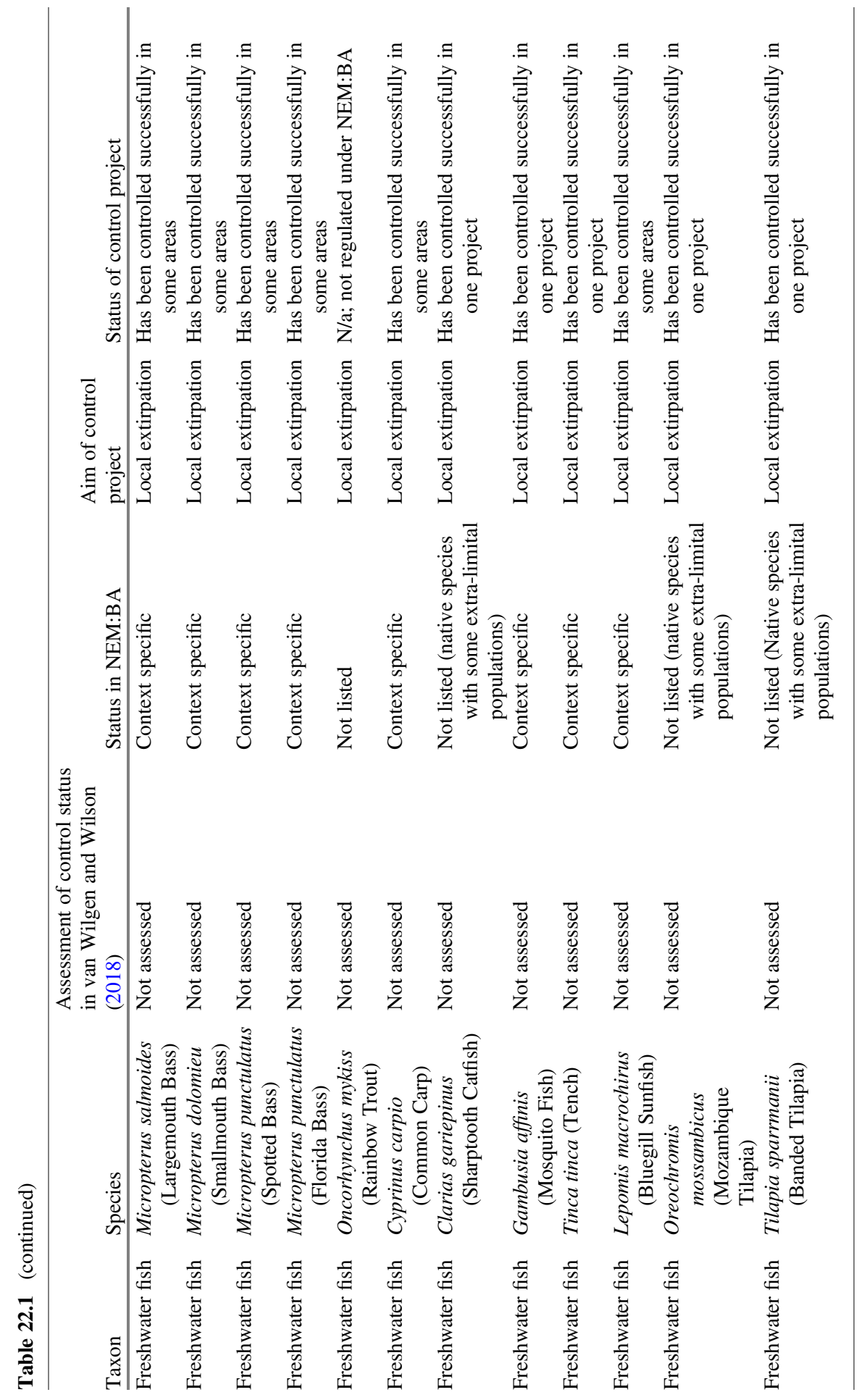




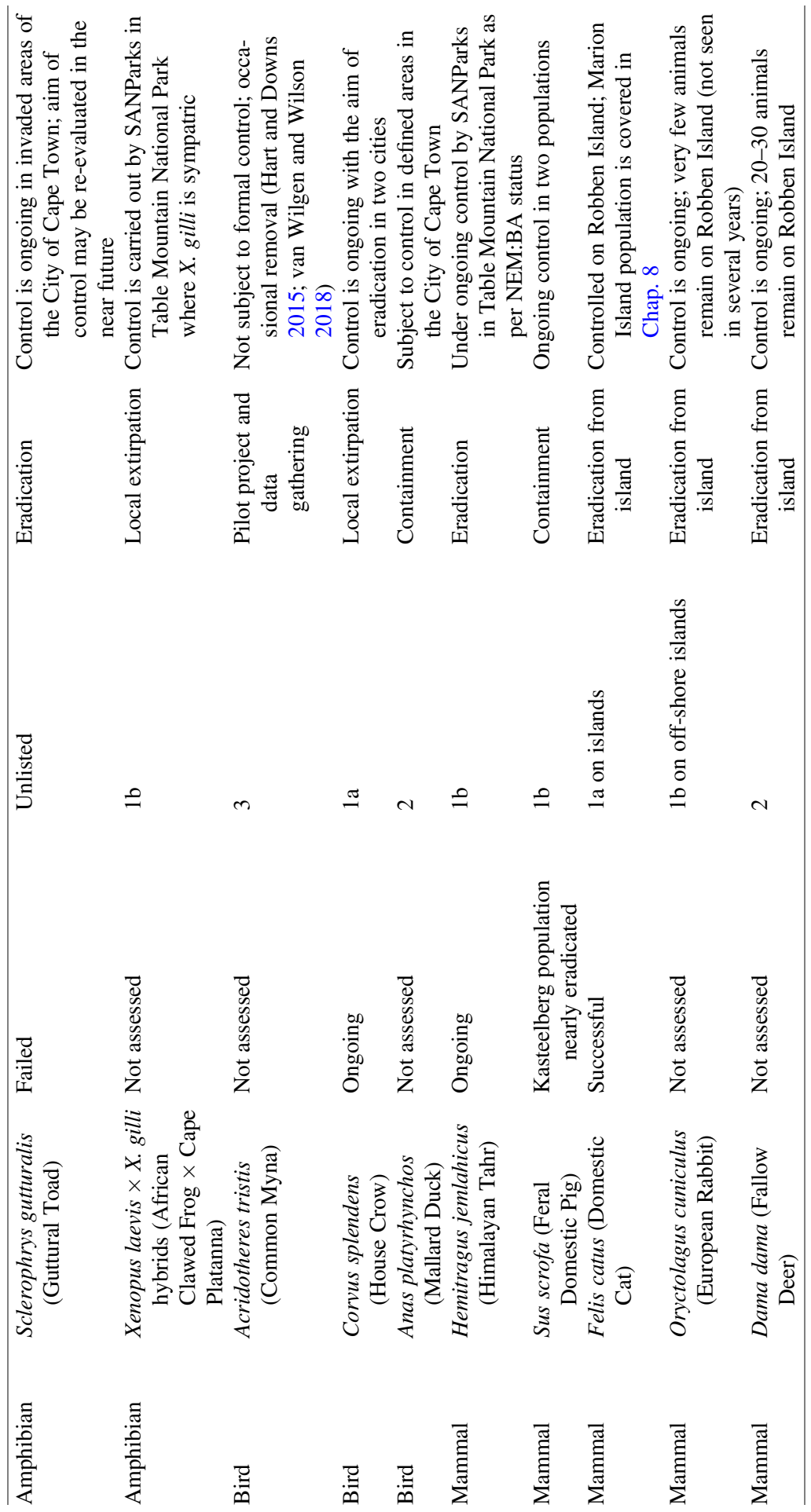




\subsubsection{Carcinus maenas (European Shore Crab)}

Carcinus maenas has a broad distribution on four continents, but is native to the north Atlantic and Baltic regions, and possibly to North Africa (see Robinson et al. 2020, Chap. 9; Hampton and Griffiths 2007). In South Africa, its distribution is restricted to two harbours on the Cape Peninsula-Table Bay and Hout Bay (Mabin et al. 2017). Between 2015 and 2016, a pilot management programme was conducted in Hout Bay harbour, as part of a PhD project on C. maenas. The results of the surveys suggested that although eradication may be feasible if sufficient management effort was to be applied, $C$. maenas is not spreading outside harbours, or into undisturbed habitats (Mabin et al. 2017). No further control is planned for this species.

\subsubsection{Tetrapygus niger (Chilean Black Urchin)}

Although not the result of a control operation, the presence and subsequent disappearance of Tetrapygus niger in South Africa deserves mention. The urchin was recorded at an onshore oyster farming facility in Alexander Bay on the north west coast of South Africa in 2007 (Haupt et al. 2010). Since the initial observation, oyster farming has ceased at Alexander Bay and the facility has been abandoned. In 2014 a re-survey of the two oyster farm dams in which the urchins has been recorded as well as nearby intertidal and subtidal habitats was performed by researchers (Mabin et al. 2015). No living T. niger were found in the dams or on the shore and the population is thought to be extinct (Mabin et al. 2015). The 2014 survey was funded by the Department of Environmental Affairs (DEA) through the South African National Biodiversity Institute (SANBI) Marine Programme. Haupt et al. (2010) judged the likely source of the urchins to be the importation of oyster spat from Chile. Since the farming operations have ceased, re-introduction through this pathway is unlikely.

\subsection{Terrestrial Invertebrates}

\subsubsection{Otala punctata (Freckled Edible Snail)}

Otala punctata is a helicid snail native to the Western Mediterranean and invasive in the United States, Argentina, Uruguay and Chile. Herbert and Sirgel (2001) recorded the eradication of $O$. punctata introduced to the Western Cape. The first population was found at Tygerberg Hospital near Cape Town in December 1986 and the second population at the Cape Town docks in January 1987 (see also Janion-Scheepers and Griffiths 2020, Chap. 7). An eradication programme was started promptly under the 
auspices of the Department of Agriculture and Water Supply, Winter Rainfall Region. The two populations were removed from 1987 to 1989, monitored through to August 1990 and no further presence of the species was detected thereafter (Herbert and Sirgel 2001). Control techniques included manual collection of snails and baiting with molluscicide (methaldehyde and methiocarb). Dense vegetation such as patches of rank grass were removed using herbicide and flame throwers so that snails could be detected more easily. The total cost of the programme was ZAR 215,000 over 3 years.

Herbert and Sirgel (2001) estimated that the Tygerberg colony initially covered about 4 ha, and that over 22,000 snails were removed from the area; the species has not been recorded subsequently. The eradication project was justified because no species of Otala had ever been reliably recorded in South Africa prior to 1986, and they were known to be invasive elsewhere. The species is not listed in NEM:BA as either an invasive or a prohibited species in South Africa. Since this is a relatively large (ca $35 \mathrm{~mm}$ diameter) polyphagous herbivore, there is a possibility it could be re-introduced in future, either for cultivation or by accident.

\subsubsection{Trogoderma granarium (Khapra Beetle)}

Trogoderma granarium is a dermestid beetle that feeds on grains and is a serious pest of stored grains such as wheat. Consumption of grain contaminated with this species has negative consequences for human health because of the numerous body parts and cast skins (Athanassiou et al. 2019). The first record of Khapra Beetle in South Africa was from imported malt in Pietermaritzburg in May 1954; sporadic records followed in disparate parts of the country until an outbreak in an intensive agricultural area in the Northern Cape Province in 1972 (Viljoen 1990). Various outbreaks continued during the 1990s in the Northern Cape and were dealt with by extensive pesticide application. It is not clear from published literature which agencies were involved in Khapra Beetle control, or what the operations cost.

According to South Africa's National Status Report (van Wilgen and Wilson 2018) this species has been eradicated. According to the European and Mediterranean Plant Protection Organisation's Global Database (EPPO 2019), this species is no longer present in SA, having been recorded at three different sites up to 1972 but failed to establish after control and quarantine measures were applied (Day and White 2016).

\subsubsection{Fruit Flies (Tephritidae) as Exemplar Invasive Insect Species}

True fruit flies (Tephritidae) have a long history of global invasions and South Africa is no exception. Among the most widely recognised globally invasive fruit fly species are 
the Mediterranean Fruit Fly (Ceratitis capitata) and the Oriental Fruit Fly (Bactrocera dorsalis). Fruit flies have a range of impacts from direct (e.g. fruit damage) to indirect, including restricting international market access and having knock-on socio-economic impacts, especially in Africa where small-scale farmers may be heavily reliant on fruit or commodity sales and trade. In South Africa, the Mediterranean Fruit Fly has long been the focus of pest management strategies, despite this region likely forming part of its historical native distribution. Although not classified as invasive within South Africa (Richardson et al. 2011; Karsten et al. 2015), the Mediterranean Fruit Fly is managed in South Africa as an agricultural pest and elsewhere (e.g. Europe) as an invasive and an agricultural pest (Karsten et al. 2018).

On the African continent, there is also a growing threat of pest and invasive fruit fly species that readily establish and can affect agricultural food security. South Africa is a signatory of the International Plant Protection Convention (IPPC), an agreement between 182 countries worldwide to protect cultivated and wild plants against invasive pest species. Trapping protocols for fruit fly detection at borders and in commercial fruit growing areas were established in South Africa in 2006 as part of a National Exotic Fruit Fly Action Plan (Barnes and Venter 2006). Several species in particular are being closely-monitored [including B. dorsalis, B. zonata and Zeugodacus (Bactrocera) cucurbitae] due to concerns surrounding their rapid spread across the African continent from their Asian origins. From its 2003 detection on the continent (Mwatawala et al. 2004; Drew et al. 2005), B. dorsalis was found at the northern South African border in 2007/2008, and only properly tackled in 2010 when detected again after no individuals were detected in 2009 (Manrakhan et al. 2009, 2011). However, in the previous year a steering committee involving industry partners and government was formed to address the growing threat of $B$. dorsalis to the South African food economy (Manrakhan et al. 2009). The detection of a confirmed B. dorsalis specimen in a trap precipitated the prescribed eradication plan. In short, a quarantine area (a circle about $80 \mathrm{~m}^{2}$ ) would be constructed around this point and a delimiting survey initiated (Manrakhan et al. 2012). Eradication efforts were then undertaken and included orchard sanitation (all fruit collected is buried $50 \mathrm{~cm}$ below ground), Male Annihilation Technique (400 blocks per $\mathrm{km}^{2}$ ) as well as protein bait sprays (Manrakhan et al. 2012). If, after 12 weeks, no further flies are detected, eradication is assumed to be successful, quarantine lifted and 'pest free' status assigned, which was the case here.

However, eventually $B$. dorsalis was detected in multiple new and previously eradicated areas and is currently established in several fruit-growing regions of South Africa (Mpumalanga, KwaZulu-Natal, Limpopo, North-West and Gauteng Provinces) (Manrakhan et al. 2015; Karsten et al. 2018), indicating failure of the eradication attempts. The current consensus aim is to manage the invasive species alongside the other pest fruit flies, and to employ a broader range of methods based on integrated pest management (IPM), for example various combinations of attractand-kill, classical biological control, introduction of natural enemies, and pesticide applications, if necessary. Although a sterile insect technique (SIT) is currently employed for the Mediterranean Fruit Fly (C. capitata) in parts of the Western Cape Province (Barnes and Venter 2006), as yet there are no plans, to our 
knowledge, to adopt a SIT program for B. dorsalis. Suckling et al. (2014) assembled a specific database for fruit flies from the Global Eradication Database (http://b3.net. $\mathrm{nz} / \mathrm{gerda} /$ ), investigating eradication and response programmes and their outcomes in 17 tephritid species worldwide. They show that for the 108 programmes targeting 13 Bactrocera species there was a $12 \%$ failure rate, compared to programmes targeting Anastrepha or Ceratitis species included in the study with no reported failures. Furthermore, B. dorsalis (including B. philippinensis, B. invadens and B. papayae after synonomisation; see Schutze et al. 2015) specifically had more official responses than any of the other Bactrocera species $(n=63)$ with eradication declared in 39 cases. It seems therefore that Bactrocera species may be inherently more difficult to eradicate than Anastrepha or Ceratitis species, as failures are more frequently reported in Bactrocera, as was the case in South Africa's Bactrocera eradication programme recently.

Despite best intentions, heightened awareness among the local population, on-going surveillance and large-scale eradication efforts, B. dorsalis' spread into South Africa was not thwarted. The reasons for this are unclear, but there are several possible explanations. For example, it may have been a consequence of high propagule pressure in the form of multiple introductions from multiple smaller, cryptic locations, combined with a large informal across-border (or within-country) fruit trade that is typically poorly regulated. However, no studies, to our knowledge, have examined these or alternative hypotheses. With new invasive Tephritidae species already making an appearance at South African borders, it is time these knowledge gaps are addressed thoroughly and the management responses carefully monitored to learn from past mistakes. In our view, an across-border and withincountry program to restrict informal fruit movement would be worth implementing to attempt to reduce the establishment of new invasive fruit fly species. Presently, two international networks (Addison et al. 2016), FRUITFLYNET (South Africa, Mozambique, Tanzania, Belgium) and the ERAfrica Fruit Fly project (South Africa, Ivory Coast, Belgium, La Réunion) are in place and both projects aim to improve trapping, surveillance and identification tools of Tephritidae pests in Africa.

\subsubsection{Polistes dominula (European Paper Wasp) and Vespula germanica (German Wasp)}

These two species are treated together here because they are both social wasp species that have global invasive distributions, and they have recently established invasive populations in South Africa. Both species are spreading and are recognised as invasive species in legislation (Category 1b invaders-RSA 2014).

Vespula germanica was first recorded in Newlands, Cape Town in 1974. For several years the range of $V$. germanica seems to have remained confined to the Cape Peninsula. However, in 2002 it was recorded in Somerset West more than $50 \mathrm{~km}$ from Cape Town, and by 2003 it was being detected in Stellenbosch, Elsenburg, southern 
Paarl, Banhoek and Sir Lowry's Pass, as well as Franschhoek by 2004. These are all centres in agricultural landscapes that sequentially border the first Boland population detected in 2002 (Haupt 2015). It is thus clear that the species suddenly underwent a rapid range expansion after being isolated on the Peninsula for many years. The species now has a much larger distribution that can increase further over time.

Polistes dominula is a more recent invader but has already spread approximately $100 \mathrm{~km}$ from its point of introduction near Cape Town in 2008. It is now common throughout the Cape Town Metropolitan Region, Somerset West, Stellenbosch, Paarl, Wellington, Franschhoek and parts of Grabouw (Veldtman et al. 2012; Benadé et al. 2014; van Zyl et al. 2018).

From 2014 the City of Cape Town, in partnership with Stellenbosch Municipality, SANBI and Stellenbosch University researchers, initiated nest removal programmes for V. germanica and P. dominula (van Zyl et al. 2018). Due to the similar appearance of the two wasp species and the seriousness of their stings (particularly $V$. germanica), the public were invited to inform the City of nests on private property, and staff were dispatched to remove nests in response. The aim of the programme was not to eradicate, but to provide a service to residents who were experiencing problems with invasive wasps on their properties. In April 2015, the City of Cape Town Invasive Species Unit reported that 6142 nests had been removed and 691.5 person days worked. At that time, members of the Invasive Species Unit noted the high volume of requests and that the extent and density of the invasion was worse than expected, and concluded that a piecemeal approach of treating individual houses would never be effective. There are however far fewer cases of $V$. germanica reports and the destruction of nests as reported could help curb the impacts experienced by residents from this species. The $V$. germanica control programme is therefore still ongoing.

From 2016 November to February 2017, SANBI initiated a systematic trial to eradicate $P$. dominula at its range edge in the Franschhoek and Grabouw areas using contractors. After training by researchers these contractor teams (three teams of five people per area) set out to visit residential properties in a 3 month period in each area to systematically record and destroy all detected $P$. dominula nests. During this period 3708 homes were checked and 15,008 nests removed in Franschhoek, while in Grabouw 3370 homes were checked and 7029 nests were removed. This equates to 1890 persons days (30 people $\times 63$ days) spent on inspecting 7078 homes and destroying 22,037 nests. The area-wide coverage and clearing effectiveness was better in Franschhoek than Grabouw, possibly because of communication difficulties in communities that speak several languages (Simakani 2017). There was no follow up work done in these areas to establish whether fewer nests were present the following season, so the effectiveness of the intervention is unknown.

For V. germanica 232 nests were destroyed between 2014 and 2018 across its distributional range (in 2014, 56; 2015, 12; 2016, 80; 2017, 23, and 2018, 61) by researchers based at Stellenbosch University, wine farms, pest control companies and the City of Cape Town. Spatial records for each of these nests will be used to model the fine scale distribution of this species (Veldtman et al. unpublished data) as a potential aid to future control strategies. The climate in the current range of 
$V$. germanica is marginally suitable for the species, but if they are able to spread into the eastern coastal strip of South Africa they could potentially occupy a much larger climatically suitable range in the sub-tropical regions of the country (Tribe and Richardson 1994; Veldtman et al. 2012). De Villiers et al. (2017) have indicated that agricultural irrigation can extend the area of suitable climate for $V$. germanica, increasing the chance of this species spreading to the east of the country. Veldtman et al. (2012) assert that eradication of $V$. germanica is only possible with continued systematic control efforts.

The situation regarding $P$. dominula is more challenging due to the large populations already present. From the eradication trial it is clear that $P$. dominula is well established even at its range edge and containment would require substantial resources to be effective. However in New Zealand, where V. germanica has completely infiltrated and taken over native ecosystems, the use of technological methods such as gene drive (where RNA-guided gene drives-based on CRISPR/ Cas9-are used to modify individuals that are then released to interfere with the reproduction of the invasive population) are being investigated as a means of eradicating their population (Lester and Beggs 2019). South Africa would benefit if New Zealand succeeds in applying and sharing this technology to develop a potential control method for $P$. dominula. Currently $P$. dominula occurs in most major towns of the Boland region. There are however high volumes of agricultural produce and equipment being moved between invaded and uninvaded areas which makes further spread via the Transport-Stowaway pathway (Convention on Biological Diversity 2014) likely.

\subsection{Freshwater Fish}

In South Africa, 27 alien freshwater fish taxa have been introduced into the wild and 16 of these are considered invasive (Ellender and Weyl 2014). Attempts to control alien fish have been restricted to a few catchments and species. While this indicates some progress in the management of invasive fish, the majority of invasive populations have not been subjected to control, and some control operations meet much resistance due to the recreational and subsistence value of certain species (Zengeya et al. 2017).

The formal management of alien fishes for biodiversity restoration was initiated in 2000 through the Cape Action for People and the Environment project (CAPE; Younge and Fowkes 2003). The CAPE project defined criteria for identifying rivers for fish control, subsequent identification of candidate rivers and identification of suitable eradication methods (Marr et al. 2012) within the Cape Fold Freshwater Ecoregion (Abell et al. 2008). The outcomes of the control projects are summarised below. 


\subsubsection{Micropterus Species (Black Basses)}

Black Bass is the collective name for species of the genus Micropterus, and four species (M. salmoides, Largemouth Bass; M. dolomieu, Smallmouth Bass; M. punctulatus, Spotted Bass and M. floridanus, Florida Bass) have been introduced into South Africa (Ellender et al. 2014; Weyl et al. 2020, Chap. 6). These species were introduced for angling and today these fishes are ubiquitous throughout the country (Ellender et al. 2014). They prey on native fishes and can cause local extirpations of highly threatened endemic fishes (e.g. van der Walt et al. 2016). All four species are listed in NEM:BA (RSA 2016) in various categories depending on their location and are therefore regulated by area. For example, M. dolomieu is permitted in discrete systems (rivers, lakes, estuaries) where it is established but must be controlled and wherever possible removed from protected areas and mountain catchments. Control of Black Bass in tributary streams has been attempted using manual eradication methods as well as piscicides. Two mechanical extirpation projects have been implemented to date with different outcomes: M. punctulatus was successfully extirpated from the Thee River in the Cederberg region (van der Walt et al. 2018), but a similar project aimed at the extirpation of M. dolomieu failed in the Blindekloof Stream in the Swartkops system (Skelton 1993; Ellender et al. 2011).

Micropterus punctulatus was discovered in 2007 in the Thee River, and CapeNature's Invasive Alien Fauna Unit initiated a manual eradication project in 2010 (van der Walt et al. 2018). Removal efforts included netting, spearfishing and electrofishing as well as the construction of an invasion barrier. Annual surveys from 2015 to 2017 indicated that the population had been successfully extirpated and that native threatened fish species had recolonised the previously invaded reach of the river. A total of 442 person days (174 for actual eradication work) were recorded across all aspects of the project (van der Walt et al. 2018).

Micropterus dolomieu was successfully removed from the Blindekloof River in 1988 by means of angling and electrofishing (Skelton 1993). However, an invasion barrier was not constructed to prevent reinvasion and management was reliant on ongoing removal efforts. Management effort was not maintained and M. salmoides reinvaded the Blindekloof River (Ellender et al. 2011).

Stakeholder conflict and resistance to the two projects described above was largely absent, as the two bass populations were of low angling value. In contrast, significant opposition and negative media perception characterised the proposed use of the piscicide rotenone in the Rondegat River to remove M. dolomieu (Marr et al. 2012). This project was implemented by CapeNature in 2012-2013 and funded mainly through the DEA: NRM programme at a cost of approximately ZAR 1.4 million (Barrow 2014). The project was implemented under the guidance of staff from the California Department of Fish and Game using Standard Operating Procedures for the use of rotenone (Finlayson et al. 2010). Micropterus dolomieu were successfully extirpated from this river following two rotenone treatments 1 year apart and upgrading of an instream weir to prevent reinvasion from downstream sources (Weyl et al. 2014). Extensive post-treatment monitoring of non-target aquatic invertebrates illustrated that 
despite short-term negative effects, the invertebrate community recovered relatively quickly to pre-intervention levels (Woodford et al. 2013; Bellingan et al. 2015, 2019). Native fish from upstream of the treatment zone successfully recolonised the treatment zone, resulting in an increased area of occupancy for these species in the absence of M. dolomieu (Weyl et al. 2014; Marr et al. 2019).

Despite initial opposition from some stakeholders, perceptions changed considerably during the project from initial scepticism and resistance, to support. This was largely the result of an independent EIA process prior to treatment, rigorous and independent scientific monitoring of all aspects of the project such ecological impacts, project success and treatment regime, and a coordinated and ongoing media and stakeholder engagement effort.

\subsubsection{Oncorhynchus mykiss (Rainbow Trout)}

Oncorhynchus mykiss were introduced to South Africa as an angling species in the late 1890s and are today considered a typical conflict species, i.e. a species with negative environmental impacts but which is also valuable from a socio-economic perspective (e.g. for angling and aquaculture) (Woodford et al. 2016; Zengeya et al. 2017; Weyl et al. 2020, Chap. 6). Due to its ability to invade headwaters, O. mykiss is especially problematic in the Cape Fold Ecoregion and in the high-lying areas of Mpumalanga and KwaZulu-Natal provinces, all of which are home to a number of endemic and highly threatened native fishes (e.g. Kleynhans 1987; Skelton 2001; Shelton et al. 2014; Weyl et al. 2015). Conflict with anglers about the removal of trout has resulted in a failure to list the species in the NEM:BA Alien and Invasive Species Regulations (RSA 2016) because of stakeholder opposition (Woodford et al. 2017). Until the impasse on the appropriate management options of $O$. mykiss is resolved, the species cannot be regulated under national legislation but is regulated under provincial conservation ordinances.

Only one control project has been implemented to date, namely a manual eradication attempt by CapeNature in the Krom River in the Cederberg (Shelton et al. 2017). The project aimed to remove $O$. mykiss from the headwaters of the Krom River, a tributary of the Olifants-Doring system, from 2013 to 2014; extirpation efforts focused on approximately $6 \mathrm{~km}$ of river, and used angling, fyke and gill nets. A significant reduction in trout numbers was achieved during the attempt, but the population returned to near its pre-removal abundance level within 2 years. The total cost of the project was approximately ZAR 150,000 which covered salaries, transport and equipment for the 40-day effort. 


\subsubsection{Cyprinus carpio (Common Carp)}

Cyprinus carpio is a global invader that was introduced to South Africa in the 1850s. As with many other invasive fishes, it is now ubiquitous throughout the country (Ellender et al. 2014; Weyl et al. 2020, Chap. 6). It is generally associated with ecosystem-level impacts such as increased turbidity and disruption of substrates and aquatic plants through their bottom-feeding behaviour (de Moor and Bruton 1988). The management of $C$. carpio is therefore important for ecosystem service protection more than for biodiversity restoration. A number of extirpation projects aimed at improving ecosystem function have been implemented to date. The Century City wetland system in Cape Town was treated with rotenone in 2008 to remove C. carpio and improve ecosystem functioning and water quality. Treatment cost was estimated at ZAR 100,000 for a once-off treatment and was funded by the Century City Home Owners Association (D. Ferreira, pers. comm.). Post-treatment monitoring indicated that $C$. carpio were reduced to below detectable levels suggesting that the species had been successfully eradicated (B. Paxton, unpublished data). Subsequent monitoring detected no $C$. carpio for 5 years, but they were detected in very low numbers in 2016. It is not clear whether the individuals found in 2016 were survivors from the original project (i.e. the extirpation failed) or were re-introduced subsequently. The project was well-supported by the general public as well as government stakeholders (e.g. Department of Water and Sanitation), due to a well-coordinated and comprehensive communication plan and a strong management presence during the treatment (D. Ferreira, pers. comm.).

In 2017, rotenone treatment of a privately-owned farm dam near Nieuwoudtville, Northern Cape, removed Cyprinus carpio that posed an invasion risk to the Oorlogskloof River in a nearby protected area. The project was implemented jointly by the two provincial departments (CapeNature and the Northern Cape Department of Environment and Nature Conservation) using DEA: NRM funding. Post-treatment monitoring indicated that the Cyprinus carpio were successfully removed (Marr et al. 2019).

\subsubsection{Clarias gariepinus (Sharptooth Catfish)}

Clarias gariepinus is native to the northern parts of South Africa but several extralimital and invasive populations exist in the Cape Fold Ecoregion (Cambray 2003; Weyl et al. 2020, Chap. 6). Only one extirpation project has been implemented to date, but it ultimately failed to achieve extirpation. Following an illegal introduction of catfish into Grey Dam near Makhanda, the Eastern Cape Nature Conservation agency, assisted by staff from Rhodes University and Albany museum, treated the dam with rotenone (Cambray 1995). The project was funded by Makhanda and while successful extirpation was reported post-treatment, subsequent reinvasion of this species was reported (Cambray 1995). 


\subsubsection{Multi-species Extirpation Projects}

Many invasive and extra-limital freshwater fish species have been co-introduced and have been the subject of multi-species extirpation efforts, either for biodiversity restoration or improving ecosystem function. Paardevlei wetland outside Cape Town is an example where a large number of invasive species, including C. carpio (Common Carp), Micropterus spp. (Black Bass), Tinca tinca (Tench) and Lepomis macrochirus (Bluegill) had been stocked since the 1920s (Impson et al. 2005). The dominance of C. carpio over time resulted in declining water quality, algal blooms and altered ecosystem function. In 2005, the wetland was treated by aerial spraying of rotenone and over 35 tons of fish, mostly C. carpio, were removed after treatment (Impson et al. 2005). The project, including a coordinated stakeholder information campaign, was designed and implemented by an independent consulting firm and funded by the landowner. There was negligible stakeholder opposition, with the exception of concerns around animal welfare. The fish have not been detected since the termination of monitoring in 2014, so the operation appears to have succeeded.

Die Oog is a small urban wetland in Cape Town that forms part of a formal conservation area managed by the City of Cape Town. The wetland is home to alien fish species such as C. carpio and Gambusia affinis (Mosquito fish) and some extra limital species like Tilapia sparrmanii (Banded Tilapia) and Oreochromis mossambicus (Mozambique Tilapia). Ecological functioning of the wetland deteriorated, mostly as a result of the large $C$. carpio population. Attempts to remove the C. carpio by draining of the wetland were unsuccessful and rotenone treatment was initiated in 2005. This successfully removed all the alien fish species and restored ecosystem functioning of the wetland. Total costs are not known, but the treatment cost was reduced through partial drainage of the wetland, thereby reducing the volume of water to be treated. The fish have not been detected since and the wetland is in a good condition and supports a number of native bird and amphibian species, including the Endangered Sclerophrys pantherina (Western Leopard Toad; Measey et al. 2012).

An off-stream dam in the Lourens River catchment outside Cape Town was treated with rotenone in 2005 to remove M. salmoides, T. sparrmanii and C. carpio. The dam is part of the Helderberg Nature Reserve, managed by City of Cape Town. CapeNature implemented the project, and removal of the invasive species allowed for the establishment of a refuge population of native fish from the Lourens River. The extirpation was successful.

\subsection{Amphibians}

Two invasive amphibian species have been identified for control operations in the greater Cape Town area: Xenopus laevis (African Clawed Frog) and Sclerophrys gutturalis (Guttural Toad). Both species pose threats to endemic native species. The 
hybrids of $X$. laevis and X. gilli are listed as requiring control (Category $1 \mathrm{~b}$ ), and $S$. gutturalis is listed as requiring control (Category $1 \mathrm{~b}$ in the Western Cape) under the Alien and Invasive Species Regulations (RSA 2016).

\subsubsection{Sclerophrys gutturalis (Guttural Toad)}

Sclerophrys gutturalis was first observed in the Western Cape in 2000 (De Villiers 2006), more than $1200 \mathrm{~km}$ from the native population to the north in Durban (Telford et al. 2019; Measey et al. 2020, Chap. 5). Environmental managers are concerned about this invasion because of the co-occurrence of endemic Endangered (IUCN 2017) Sclerophrys pantherina (Western Leopard Toad) in the same area. Guttural Toads have been subject to control operations in the City of Cape Town since 2010. The aim of the programme is to extirpate the species in the City and prevent its re-introduction. The City of Cape Town's Invasive Species Unit has contracted a private firm to locate and remove toads at a cost of approximately ZAR 200,000 per annum. The firm works closely with municipal staff to visit land owners, undertake nocturnal searches and remove toads from private property and green areas. All life stages were targeted for removal until demographic modelling revealed that removal of eggs and tadpoles had very little impact on population numbers and that effort was best expended on removing juvenile and adult toads (Vimercati et al. 2017a). During the 8 years of the control operation, the invaded area has increased from a few properties in one suburb to occupy about $5 \mathrm{~km}^{2}$ in 2009 and over $8 \mathrm{~km}^{2}$ by 2015 (Measey et al. 2017). Records of toads in outlying suburbs on the southern side of the Cape Peninsula mountain chain have raised concern that human-mediated jump dispersal could significantly increase the invaded area although such populations have not yet established.

Bureaucratic delays also impact negatively on the project's effectiveness. Each year, a new contract has to be issued and delays in the contract process and the availability of funds can cause delays of several months after the start of the breeding season in October/November. In most years, management only commences in December or January, providing ample opportunities for the toad population to increase and occupy new ponds in the first part of the breeding season. Gaining access to numerous private properties in this high-income, low density, housing area has been a major impediment to control, with models suggesting that missing $55 \%$ of properties undermines the total management effort with no net effect (Vimercati et al. 2017b; Potgieter et al. 2020, Chap. 11). The Guttural Toad management effort has been sustained until the present, but based on the recent data researchers and managers have discussed the possibility of changing the aim of the control operation from extirpation to containment, because without increased effort and dedicated long-term funding, it is unlikely that extirpation will be achieved. 


\subsubsection{Xenopus laevis (African Clawed Frog)}

Xenopus laevis is widespread throughout southern Africa (Furman et al. 2015), and in the Western Cape it is sympatric with $X$. gilli, the endemic, range restricted Cape Platanna (Endangered-IUCN 2017). However, the original range of $X$. laevis remains unclear (Measey et al. 2017). Furthermore, research strongly suggests that the presence of $X$. laevis in the same water bodies reduces recruitment of $X$. gilli through competition and predation (De Villiers et al. 2016; Vogt et al. 2017; Thorp et al. 2019). Early research suggested that introgression was a threat to $X$. gilli (Picker et al. 1996), and this formed the basis of NEM:BA listing hybrids of $X$. gilli and X. laevis for removal. However, more recent genetic studies suggest that while F1 hybrids form between the species, there is no introgression (Furman et al. 2017).

From 1985 to 2000, several thousand X. laevis were removed from the Cape of Good Hope section of Table Mountain National Park (TMNP) with the aim of protecting the population of $X$. gilli from genetic introgression in the National Park (Picker and De Villiers 1989; De Villiers 2004). After a hiatus of 10 years in $X$. laevis population control and as part of a research project conducted in collaboration with SANParks protected area management staff between 2010 and 2014, a total of 2126 X. laevis were removed from the Cape of Good Hope section of TMNP (Measey et al. 2014; De Villiers et al. 2016; Measey et al. 2017). Annual operations are still underway to date (March 2019) in a collaboration between the Organisation for Tropical Studies, SANParks and the C.I.B. Extirpation is not considered possible as $X$. laevis regularly enter the park via streams from dams on adjacent private land.

\subsection{Reptiles}

No introduced reptile species are currently being controlled in South Africa.

\subsection{Birds}

Five invasive bird species have been considered for control or eradication in South Africa to date: Acridotheres tristis (Common Myna), Columba livia (Common Pigeon), Corvus splendens (House Crow), Anas platyrhynchos (Mallard) and Psittacula krameri (Rose-ringed Parakeet). Common Mynas are ubiquitous in many cities and towns around South Africa (see Measey et al. 2020, Chap. 5; Potgieter et al. 2020, Chap. 11), but no large-scale or systematic control has been attempted. However, in parts of KwaZulu-Natal province, A. tristis trapping trials have been conducted with the result that birds have been removed from local areas. Evidence for strong negative impacts on avian and other species (Hart and Downs 2015) by 
A. tristis is lacking, but as A. tristis are fruit and nectar feeders and are known to damage fruit crops (Gumede and Downs 2019) it is likely that impacts do occur.

Columba livia is controversial because it exists as feral populations which interact with captive populations used as pets and for pigeon racing. Currently there are no systematic control programmes for this species (Measey et al. 2020, Chap. 5).

Corvus splendens and A. platyrhynchos are under ongoing control in Durban and Cape Town, in operations funded by DEA: NRM and supported by a range of institutions, principally local authorities. The two avian control projects are covered in more detail below.

Rose-ringed Parakeets Psittacula krameri are established as breeding colonies in metropolitan areas of Gauteng, Durban and Cape Town and smaller towns and cities Steytlerville and Pietermaritzburg (Hart and Downs 2014). The Rose-ringed Parakeet is listed in Category 2 of NEM:BA, but has only been controlled on a small scale in Somerset west, where birds were caught and removed from a single dwelling resulting in local extirpation (L. Stafford, pers. comm.).

\subsubsection{Corvus splendens (House Crow)}

The Cape Town population has been under continuous management since 2009 and has been reduced from a peak population of 10,000 in 2010 to about 300 individuals. The eThekwini (Durban) population was at very low levels (thought to be $<10$ individuals), but recovered following a suspension of management due to cessation of funding from the government in 2017. In early 2018 a new monitoring and control programme was funded by DEA: NRM and eThekwini Municipality, and is ongoing. Other populations of $C$. splendens occur in Richards Bay and East London. The Cape Town and eThekwini programmes aim to extirpate the species from these locations. Over ZAR 8 million has been spent on the programme over 8 years of active control using poison baits and trapping at House Crow roosting and feeding sites.

As is common in eradication projects, the last few animals are difficult to detect and remove, especially given the high intelligence of these birds which learn to avoid people and baiting areas (Suliman et al. 2011). It is thought that novel approaches will need to be employed to finally achieve extirpation in the four coastal cities that are currently invaded and funding for continued monitoring is likely to be required in perpetuity due to the high risk of reintroduction at these ports.

\subsubsection{Anas platyrhynchos (Mallard)}

Anas platyrhynchos hybridise with native Anas undulata (Yellow-Billed Ducks). It was thought that genetic introgression and A. platyrhynchos aggressive competitive behaviour may lead to suppression of native duck populations in urban and peri- 
urban areas and loss of genetic integrity and identity in these taxa. However, recent genetic studies have shown that introgression occurs from $A$. undulata into A. platyrhynchos (Stephens et al. 2020). The presence of A. platyrhynchos on farms and in rural settings also suggests that their populations should be reduced. Because of the widespread distribution of both A. platyrhynchos and A. undulata in South Africa, eradication is not an objective of this programme.

As A. platyrhynchos often swim in groups with A. undulata, the control programme opted to feed target mallards and putative hybrids bread soaked with anaesthetic (alpha-chloralose). All ducks in the urban area are habituated to people feeding them bread. Once ducks have succumbed to the anaesthetic, they are collected by kayakers waiting in the water, and transferred to a nearby facility where a duty vet euthanises A. platyrhynchos and hybrids. The carcasses are then sampled for DNA and removed by the City of Cape Town. The majority of birds removed (63\%) were found to be hybrids (Stephens et al. 2020). The programme was efficiently identifying and removing hybrids, with $5 \%$ being pure yellow-billed ducks (Stephens et al. 2020). The goal of this project is containment- the removal of A. platyrhynchos and their hybrids in areas of high abundance of both alien and native ducks in order to conserve the genetic integrity of $A$. undulata.

\subsection{Mammals}

\subsubsection{Hemitragus jemlahicus (Himalayan Tahr)}

An isolated population of Hemitragus jemlahicus is established on Table Mountain in Cape Town (Measey et al. 2020, Chap. 5). Despite originating from only a few zoo escapees, 330 individuals were counted during a survey in the 1970s (Lloyd 1975; Skead et al. 2011). The broad dietary preferences of these animals, along with their tendency to aggregate, resulted in significant environmental degradation and erosion at high densities (Lloyd 1975). As such, the authorities in charge of Table Mountain (Department of Nature and Environmental Conservation, now CapeNature, followed by SANParks from 1998), have conducted Himalayan Tahr removal programmes since the early 1970s, with the view to restoring populations of native ungulates in their place (Lloyd 1975; Gaertner et al. 2016). Public concerns over animal welfare of the tahrs have received significant media attention over the years (Gosling 2002; Skead et al. 2011).

Management interventions reduced tahr densities to a point that sightings became a newsworthy occurrence (Skead et al. 2011). However, complete eradication has not been achieved. The rugged and inaccessible mountainous terrain, exacerbated by low detectability of individuals at low population densities, make it difficult to implement management interventions. Tahrs have also been introduced to New Zealand, where they are established and have been well-studied (e.g. Forsyth and Tustin 2001; Cruz et al. 2017). However, no research has been published on the ecology, space use or management of this species on Table Mountain. Research is 
required, particularly in light of the re-introduction of Klipspringers (Oreotragus oreotragus) to the mountain and the need to understand the interactions between the two species. Hemitragus jemlahicus is listed in NEM:BA as a Category 1a species, for which mandatory control is required ('must be combatted or eradicated'-RSA 2016).

\subsubsection{Sus scrofa (Domestic Pig)}

Invasive populations of Sus scrofa (feral Domestic Pigs and their hybrids) in South Africa are descendants of Eurasian Wild Boars released by the Department of Forestry in the 1920s and 1930s, and Domestic Pigs escaped from farms (Measey et al. 2020, Chap. 5). The original intention was to control Pine Emperor Moth (Gonimbrasia cytherea) populations in plantations of the Western Cape (Botha 1989). Today, three populations are present on farms and protected areas in the Western Cape (Skead et al. 2011). The feral pigs eat rare geophytic plants and the Critically Endangered Geometric Tortoise (Psammobates geometricus) adults, juveniles and eggs, making them a conservation concern. They also have a negative impact on agricultural crops.

In 2014, feral S. scrofa were listed as Category $1 \mathrm{~b}$ invaders under NEM:BA. In 2011 CapeNature, the provincial conservation authority, produced a Feral Pig Management Strategy. The strategy covered effective control measures, monitoring of the effects of control, and prevention of re-introduction, and presented a comprehensive communication strategy to raise awareness of the presence and negative impacts of feral Domestic Pig populations. Starting in 2014, CapeNature conducted a pilot trial of feral Domestic Pig control by using baited traps and Judas pigs. This programme resulted in the removal of over 1200 pigs from the Kasteelberg and Porseleinberg populations, in addition to those removed by the land owners through hunting. The Kasteelberg population is close to extirpation (van Wilgen and Wilson 2018). The implementation of this project is carried out by a private contractor and funded by DEA: NRM.

\subsubsection{Felis catus (Domestic Cat)}

In South Africa, Felis catus is listed as Category 1a on islands, which means that they must be eradicated from islands. Felis catus has been successfully eradicated on sub-Antarctic Marion Island (Bester et al. 2002) and on Dassen Island, an inshore island off the west coast (Cooper and Dyer 2013). The successful eradication of $F$. catus from Marion island stands as an outstanding example of the eradication of an invasive vertebrate globally (see Greve et al. 2020, Chap. 8).

Felis catus has existed as feral populations on Robben Island since the late 1800s (Measey et al. 2020, Chap. 5). Felis catus is responsible for the deaths of native small vertebrates, invertebrates, terrestrial and sea birds, and likely poses a threat for 
the important colonies of threatened African Penguins (Spheniscus demersus) on Robben Island. Domestic Cats were also kept as pets, until this was banned by the Robben Island Museum management authority in 2009. As a result of the current control programme, which has removed $109 \mathrm{~F}$. catus since its inception in 2009, the feral cat population is very low, estimated at five to ten individuals $(C$. Wilke, pers. comm). In terms of the Natural Environmental Policy (Robben Island Museum 2016) the introduction of $F$. catus to the Island is prohibited and all pet cats have been removed.

\subsubsection{Oryctolagus cuniculus (European Rabbit)}

Oryctolagus cuniculus were introduced to several near-shore islands along the east coast and west coast by the early Dutch settlers in the 1600s (Measey et al. 2020, Chap. 5). After several unsuccessful introductions, the populations became selfsustaining on five islands-Bird Island near Port Elizabeth and Robben, Dassen, Schapen and Malgas Islands along the west coast. Oryctolagus cuniculus have had serious negative impacts on the native vegetation of the islands, as has been documented for other oceanic islands (reviewed in Bergstrom et al. 2009). Oryctolagus cuniculus has been listed as Category $1 \mathrm{~b}$ for islands (i.e. must be controlled) in NEM:BA (RSA 2016). However, the populations on Dassen Island off the west coast, and Schapen and Malgas Islands in Saldanha Bay are not under management at present and population sizes are not known. The population on Bird Island was eradicated in the 1980s (C. Wilke pers. comm.).

On Robben Island, the total population in 2003 was estimated to be $2137 \pm 453$ in 2003 and by November 2008 an estimated population of 24,229 (De Villiers et al. 2010). De Villiers et al. (2010) judged the population fluctuations to be induced by the availability of food resources and predation by $F$. catus. A control operation commenced in 2008, managed by Robben Island Museum. An estimated 13,600 $O$. cuniculus were removed during this time and, at the time of writing, O. cuniculus have not been seen on the island for several months, but are not yet extirpated (C. Wilke, pers. comm.). Initially, O. cuniculus were trapped and euthanised, but since 2009 night-shooting has been employed as this is more efficient, having accounted for 10,638 of the above mentioned animals, and can be conducted in conjunction with F. catus and Dama dama (Fallow Deer) control. The control operation will continue until the stated objective of eradication from the island is reached.

\subsubsection{Dama dama (Fallow Deer)}

Dama dama were introduced on Robben Island from Rhodes' Estate in 1963 (Chapman and Chapman 1980, see Measey et al. 2020, Chap. 5). Initially three 
animals were introduced, but by 1977 there were about 40 individuals on the Island. Hunting began in 1985, and the population was quickly reduced to 12 later that year. While the Island was managed as a prison, the Fallow Deer were regularly culled for sport and to provide meat, but since the facility has been managed as a museum and World Heritage Site (since 1996) the population has expanded significantly. A concerted culling and translocation operation in 2009 removed over 280 animals, and about 30-50 remained. In the ensuing years this population rebounded to over 300 animals by 2017 which prompted a renewed culling operation (C. Wilke pers. comm.) with the aim of eradicating Fallow Deer from the Island.

While there was initially some public opposition to control of Fallow Deer, monitoring by officers of the Society for Prevention of Cruelty to Animals (SPCA) and the condition of the deer on the island have added support for the project from an ethical perspective. Dama dama that have died on the island have been found to have ingested large amounts of waste plastic that has been deposited on the island from the ocean; this has resulted in the deaths of a number of deer, particularly adult females. Analysis of stomach contents of 255 deer culled since 2017 have shown that $37 \%$ of the population has ingested plastic (C. Wilke pers. comm.).

\subsection{Synthesis}

Invasive alien animal control projects are responses to complex problems that often defy simple, linear solutions (i.e. wicked problems-Woodford et al. 2016). In addition, the proposed solutions themselves, such as the projects described here, often become wickedly difficult to implement and are themselves subject to change as implementation takes place. This is a widely acknowledged problem in conservation practice, where large spatial scales, stakeholder diversity and multi-faceted contexts combine to confound solutions (Game et al. 2014). There is no right answer to many conservation problems, and one actor's optimal solution may be completely unacceptable or simply non-optimal to another actor, and the "multitude of conflicting perspectives, objectives, and management goals can make the problem almost impossible to characterise, let alone solve, to the satisfaction of all stakeholders" (Woodford et al. 2016). The acceptability of trade-offs such as animal welfare concerns is also sensitive to value systems, interests and cultural contexts, as shown in several of the projects described here.

\subsubsection{Species Which Are Not Yet Under Adequate Control}

Over 80 animal taxa (including some groups of hybrids) are listed as Category 1a or $1 \mathrm{~b}$ in NEM:BA, thus placing an obligation on landowners to eradicate or control them, but only 28 have been or are currently controlled (Table 22.1). Much further action will be necessary to ensure that more of the Category 1 species are adequately 
controlled; to increase the impact of control operations, stakeholder management, authority engagement and collaboration and learning from existing experience will be highly beneficial.

\subsubsection{Stakeholder Management}

If invasive animal populations are going to be effectively controlled, strong collaborative relationships between institutions and between local government and civil society bodies and NGOs will be necessary. Three working groups (KwaZulu-Natal Invasive Alien Species Forum, CAPE Invasive Alien Animal Working Group in the Western Cape and the national Marine Alien and Invasive Species Working Group) are actively addressing issues related to the management of invasive alien animal populations. These groups are valuable for improving the flow of information between environmental managers in local and provincial government, researchers and NGOs, and contribute to networking and building and maintaining working relationships between individuals and institutions involved in invasive animal control. However, there is further work to be done in public engagement, media relations, social media, and the nature and timing of publicity in projects supported by the working groups.

The working groups also play an important role in supporting, and in some cases designating, champions for individual projects. For example, in the case of the Rondegat River M. dolomieu project, from the initiation of the project (environmental impact assessment) in 2008 to implementation in 2012-2013, the project was championed by the ichthyologist at CapeNature Scientific Services with the support of the CAPE IAA WG and other colleagues. The support of the working group was deemed essential to keeping the process on track through long delays and strong opposition from stakeholder groups (D. Impson pers. comm.).

\subsubsection{Conflict Management}

Public opposition to animal control operations can result in significant delays (Zengeya et al. 2017). On the other hand, where the public is supportive, this can greatly improve detections and improve relationships between stakeholder groups, as in the case of the invasive wasp species $V$. germanica and $P$. dominula in Cape Town. Among the projects described in this chapter, there have been a range of responses by public and stakeholder groups ranging from outright support (e.g. V. germanica, $P$. dominula and C. splendens) to strong conflict with multiple groups (e.g. A. playrhynchos and H. jemlahicus). Gaertner et al. (2016) constructed a framework for classifying invasive species into management classes based on their impacts and conflicts with particular reference to cities. Five possible management responses were then identified based on species impact, value and level of conflict experienced or expected. The management options are to tolerate, monitor, contain, 
control or eradicate. The authors point out that decision making in response to invasive species in cities has to be rapid, because of the spread rates and the rapidity with which invasive species populations become unmanageable (Gaertner et al. 2016). Similarly, conflicts also have to be managed rapidly, so that management can get off the ground as early as possible in the invasion process.

Participatory working groups, such as the three invasive species working groups established in South Africa to date, can assist invasive species managers to rapidly scope and initiate data gathering, stakeholder engagement and control operations. Since these groups contain a greater range of stakeholders than would typically be available for invasive species managers to consult, they broaden the debate and create awareness of the range of different perspectives that are likely to come from the public. Also, they allow other participants, for example, researchers, to understand the needs of managers and to target their research towards useful outcomes. A good example of this is the study that was initiated by a researcher involved with the CAPE IAAWG, who engaged a doctoral student to work on the Guttural Toad invasion. The study revealed through demographic modelling that collecting eggs and larvae of the toads has little impact on populations, and that management effort would be better expended on collecting adults. The range of experience held by the working group's network can be quickly brought to bear on new problems where there is initially very little definite information available (e.g. taxon-specific research studies) and urgent action is needed.

Gaertner et al. (2016) state that although stakeholders may have an incomplete understanding of the issues surrounding invasive species impacts and their interactions with native species and ecosystems, a wide range of views needs to be aired and considered during the decision-making process. From a study using cognitive hierarchy theory and risk perception frameworks, an expert group of assessors concluded that more conflicts arose over intrinsic values than utilitarian ones (Zengeya et al. 2017). This mirrors our findings, as the strongest conflicts experienced in South African cases (e.g. A. platyrhynchos, D. dama and H. jemlahicus) have been related to the ethics and techniques of removing and killing the animals. Alternative solutions such as leaving the animals where they are or translocating them to another habitat (potentially even back to the native range) have been endorsed by residents' groups and concerned individuals. In contrast, when the negative impacts of the species on humans were clearly recognised by stakeholders, no opposition was experienced by managers. The $V$. germanica and $P$. dominula projects have proceeded without strong public opposition.

In the context of the legislative requirement to manage invasive species (e.g. through the NEM:BA Alien and Invasive Species Lists), the effective management of conflicts to produce acceptable and practicable solutions is essential, as ultimately the control operation needs to proceed without excessive delays. Novoa et al. (2018) devised four categories of stakeholders based on impact: context setters, key players, crowd and subjects. These groups highlight the diversity that exists among invasive species conflicts and how different groups can be approached. For example, empowering stakeholders who currently have little influence or are 'hidden' from the public eye can build understanding, capacity and support for some initiatives (Novoa et al. 2018). This perspective may go some way to explaining why 
the projects involving wasps and House Crows did not result in significant opposition from stakeholder groups, as the societal costs of these species' presence in Cape Town were clear and did not require appreciation of impacts on ecosystems or the receiving environment (see Sect. 22.8.1).

\subsubsection{Scaling $U p$}

The acquisition of knowledge, better communication and awareness of the successes and failures of stakeholder engagement and options for improving practice are advancing but more work is urgently needed. Many of the control operations described above were undertaken at a local level-i.e. aiming to control a particular population or set of populations within a municipality or protected area-rather than on a national or subcontinental level. Conducting invasive and alien animal control operations at a local level is probably more effective-many of these operations were successful because they involved relatively small stakeholder groups and were flexible and efficient in response to changing circumstances and available techniques and tools. However, although local control operations are appropriate when the spatial scale of the invasion is small or contained, they can increase the chances of re-invasion from outside the control area if all populations are not addressed simultaneously. This is likely to be the case when the distribution of invasive populations is patchy and invasion pathways cannot be completely shut down.

House Crows are present in four widely spread in the port cities of Richards Bay, Durban, East London and Cape Town, which span the latitudinal extent of South Africa's coastline. Re-invasion through established pathways (Convention on Biological Diversity 2014) such as shipping (transport-stowaway) or the pet trade (release from confinement) is possible and likely in some cases. Therefore, South Africa requires an effective mechanism for scaling individual local operations up to work across provincial and perhaps national boundaries in cases where invasions are widespread. In particular, learning needs to be transferred between the levels of government, for example from local authority level to provincial and national agencies. Inter-institutional fora such as provincial and national working groups will be vital in establishing these broader channels of interaction.

\subsubsection{Financial and Contract Management}

Where external service providers are contracted to carry out operations, the administration and monitoring of these contracts becomes highly important. For example, several of the projects discussed here are carried out partly or entirely by private companies that specialise in invasive alien animal control. The projects on Guttural Toads and House Crows were delayed due to breaks in funding, resulting in lost opportunities and unchecked increases in the invasive populations. To avoid these 
breaks in funding, depending on the timing of financial cycles in the branch of government that is funding the operation, administrative processes may have to be initiated before the end of the previous financial year or bridging funds supplied to ensure that there is no break in resource availability.

\subsubsection{Critical Assessment of Control Efforts to Date}

This review has shown that the regional and eco-regional (e.g. marine) working groups have been highly effective in some cases where control or eradication, complementing the efforts of government and private partners. In the long-term, these groups must be supported to continue their work by the institutions that employ the members and support the secretariats. The question of whether the control projects that have been undertaken to date represent an adequate return on investment, is important, and needs to be addressed in future.

Ongoing re-assessment and monitoring of control efforts is important, and the goals of control projects should not be static but should be regularly re-evaluated. The value of advisory forums such as the CAPE IAAWG and the KZN Invasive Alien Species Forum is that there is a scheduled trigger for re-evaluation of project feasibility as regular meetings are held, bringing most or all of the required stakeholders together each time. At the same time, sustaining operations is important even when it seems that progress is sometimes not being made rapidly. The initiation costs of management and control projects are high, so current operations should be sustained despite temporary pressure to discontinue, such as funding delays.

The research reflected in this chapter has shown that the control of one species (C. maenas, European Shore Crab) is not necessary due to it not spreading outside harbours and the small chance of it becoming invasive on our highly energetic coastline. Species that can realistically be extirpated/eradicated by sustaining or increasing the current efforts are: Himalayan Tahrs (H. jemlahicus), Fallow Deer (D. dama), House Crows (C. splendens) and on islands Domestic Cats ( $F$. catus) and European Rabbits $(O$. cuniculus). It is unlikely that the 12 freshwater fish species covered here will be eradicated, but ongoing control in priority catchments and protected areas is important for conservation purposes, given the high levels of endemism in the Western Cape. Eradication of the two species of wasps (V. germanica and $P$. dominula) may be feasible, depending on the project designi.e. quick response to public reports of nest identification (Veldtman et al. 2012). In these two cases, large-scale efforts that span several local authorities and towns will have to be made, with guaranteed long-term funding from the national level.

Control of Mallards and Guttural Toads is in progress at a local authority level, but is not likely to lead to local extirpation of these species in the near term. It is likely that the goals of these projects may be re-evaluated in the near future. Species that are not under comprehensive control at present, such as A. tristis (Common Myna) require further research to determine the feasibility of control, some of which is being conducted at present. Xenopus laevis $\times X$. gilli hybrids are being removed from one protected area (TMNP) but are not systematically controlled anywhere else 
in the range of $X$. gilli. Overall, the picture is one of varied, context-specific control projects being run at local scale. These efforts need to be scaled up to cover regional, national or larger areas if alien and invasive animals are to be controlled more effectively.

As shown in the examples and discussion above, managing stakeholders, resolving conflict, ensuring sustained funding and scaling efforts up to larger spatial and temporal scales all involve collaborative efforts that extend outside ordinary organisational and political boundaries. Involving role players as early as possible in the planning process is a key aspect of successful projects. Also, recognising the trade-offs among costs and benefits accruing to role players and "who loses, who pays, and who benefits" (Hirsch et al. 2010) can open the way to productive rather than conflictual relationships with stakeholders. Open and transparent communication among role players builds trust and facilitates learning from perceived successes and failures (Game et al. 2014).

Network governance (see Scarlett and McKinney 2016) has been used by several provincial and national invasive alien species working groups in South Africa to harness public, private and non-profit organisational expertise and carry out invasive alien species management projects. This way of actively collaborating achieves objectives that could not be achieved by one or two role players alone. Sustaining these approaches will advance future efforts to control invasive alien animal species in South Africa.

Acknowledgements We are grateful to the CAPE Invasive Alien Animals Working Group, Christopher Wilke, Sabelo Madlala, Deborah Winterton, Gavin Bell, Dean Impson, Louise Stafford, and Dean Ferreira for their constructive inputs. We would like to thank the DSI-NRF Centre of Excellence for Invasion Biology and the Natural Resources Management Programme of DEFF for their support. DEFF are also thanked for funding the South African National Biodiversity Institute noting that this publication does not necessarily represent the views or opinions of DEFF or its employees.

\section{References}

Abell R, Thieme ML, Revenga C et al (2008) Freshwater ecoregions of the world: a new map of biogeographic units for freshwater biodiversity conservation. Bioscience 58:403-414. https:// doi.org/10.1641/B580507

Addison P, Cugula D, Daneel J-H et al (2016) Networking projects on fruit flies between Europe and Africa. In: Poster at 3rd international symposium of tephritid workers of Europe, Africa and the Middle East, Stellenbosch

Athanassiou CG, Phillips TW, Wakil W (2019) Biology and control of the Khapra Beetle, Trogoderma granarium, a major quarantine threat to global food security. Annu Rev Entomol 64:131-148. https://doi.org/10.1146/annurev-ento-011118-111804

Barnes BN, Venter J-H (2006) The South African fruit fly action plan-area-wide suppression and exotic species surveillance. In: Proceedings of the 7th international symposium of fruit flies of economic importance, pp 271-283

Barrow SB (2014) Contrasting impact of alien invasive sport fish in the Cape Floristic Region: a focus on Micropterus dolomieu. MSc Thesis, Stellenbosch University 
Bellingan TA, Woodford DJ, Gouws J, Villet MH, Weyl OLF (2015) Rapid bioassessment of the effects of repeated rotenone treatments on invertebrate assemblages in the Rondegat River, South Africa. Afr J Aquat Sci 40:89-94. https://doi.org/10.2989/16085914.2014.984651

Bellingan TA, Hugo S, Woodford DJ et al (2019) Rapid recovery of macroinvertebrates in a South African stream treated with rotenone. Hydrobiologia. https://doi.org/10.1007/s10750019-3885-Z

Benadé PC, Veldtman R, Samways MJ et al (2014) Rapid range expansion of the invasive wasp Polistes dominula (Hymenoptera: Vespidae: Polistinae) and first record of parasitoids on this species and the native Polistes marginalis in the Western Cape Province of South Africa. Afr Entomol 22:220-225. https://doi.org/10.4001/003.022.0104

Bergstrom DM, Lucieer A, Kiefer K et al (2009) Indirect effects of invasive species removal devastate World Heritage island. J Appl Ecol 46:73-81. https://doi.org/10.1111/j.1365-2664. 2008.01601.x

Bester MN, Bloomer JP, van Aarde RJ et al (2002) A review of the successful eradication of feral cats from sub-Antarctic Marion Island, Southern Indian Ocean. S Afr J Wildl Res 32:65-73

Botha SA (1989) Feral pigs in the Western Cape Province: failure of a potentially invasive species. South Afri For J 151:17-25. https://doi.org/10.1080/00382167.1989.9630500

Cambray JA (1995) Sandelia bainsii will it be next? Ichthos 45:2-3. https://doi.org/10.1007/ BF00005228

Cambray JA (2003) The need for research and monitoring on the impacts of translocated sharptooth catfish, Clarias gariepinus, in South Africa. Afr J Aquat Sci 28:37-41. https://doi.org/10.2989/ 16085910309503786

Chapman NG, Chapman DI (1980) The distribution of fallow deer: a worldwide review. Mammal Rev 10:61-138. https://doi.org/10.1111/j.1365-2907.1980.tb00234.x

Convention on Biological Diversity (2014) Pathways of introduction of invasive species, their prioritization and management. UNEP/CBD/SBSTTA/18/9/ Add.1. Secretariat of the Convention on Biological Diversity, Montreal. https://www.cbd.int/doc/meetings/sbstta/sbstta-18/offi cial/sbstta-18-09-add1-en.pdf. Accessed 19 Feb 2019

Cooper J, Dyer BM (2013) The eradication of feral cats from Dassen Island: a first for Africa? Aliens 33:35-37

Cruz J, Thomson C, Parkes JP et al (2017) Long-term impacts of an introduced ungulate in native grasslands: Himalayan tahr (Hemitragus jemlahicus) in New Zealand's Southern Alps. Biol Invasions 19:339-349. https://doi.org/10.1007/s10530-016-1283-2

Day C, White B (2016) Khapra beetle, Trogoderma granarium interceptions and eradications in Australia and around the world. SARE working paper 1609, School of Agricultural and Resource Economics, University of Western Australia, Crawley

de Kock KN, Wolmarans CT (2008) Invasive alien freshwater snail species in the Kruger National Park, South Africa. Koedoe 50:49-53. https://doi.org/10.4102/koedoe.v50i1.126

De Moor IJ, Bruton MN (1988) Atlas of alien and translocated indigenous aquatic animals of southern Africa. South African National Scientific Programmes Report 144

De Villiers A (2006) Bufo gutturalis Power, 1927. Guttural Toad. Introduced population. African Herp News 40:28-29

De Villiers AL (2004) Xenopus gilli Rose and Hewitt, 1927. In: Minter LR, Burger M, Harrison JA, Braack HH, Bishop PJ, Kloepfer D (eds) Atlas and red data book of the frogs of South Africa, Lesotho and Swaziland. SI/MAB Series \#9. Smithsonian Institution, Washington, DC, pp 260-263

De Villiers MS, Mecenero S, Sherley RB et al (2010) Introduced European rabbits (Oryctolagus cuniculus) and domestic cats (Felis catus) on Robben Island: population trends and management recommendations. S Afr J Wildl Res 40:139-148. https://doi.org/10.3957/056.040.0205

De Villiers FA, de Kock M, Measey GJ (2016) Controlling the African clawed frog Xenopus laevis to conserve the Cape platanna Xenopus gilli in South Africa. Conserv Evid 13:17-17

De Villiers M, Kriticos DJ, Veldtman R (2017) Including irrigation in niche modelling of the invasive wasp Vespula germanica (Fabricius) improves model fit to predict potential for further spread. PLoS One 12:e0181397. https://doi.org/10.1371/journal.pone.0181397 
Drew RAI, Tsuruta K, White IM (2005) A new species of pest fruit fly (Diptera: Tephritidae: Dacinae) from Sri Lanka and Africa. Afr Entomol 13:149-154

Ellender BR, Weyl OLF (2014) A review of current knowledge, risk and ecological impacts associated with non-native freshwater fish introductions in South Africa. Aquat Invasions 9:117-132. https://doi.org/10.3391/ai.2014.9.2.01

Ellender BR, Weyl OLF, Swartz ER (2011) Invasion of a headwater stream by non-native fishes in the Swartkops River system, South Africa. Afr Zool 46:39-46. https://doi.org/10.3377/004.046. 0116

Ellender BR, Woodford DJ, Weyl OLF, Cowx IG (2014) Managing conflicts arising from fisheries enhancements based on non-native fishes in southern Africa. J Fish Biol https://doi.org/10.1111/ jfb.12512 Available online at www.wileyonlinelibrary.com

EPPO (2019) EPPO global database (available online). Accessed 9 Jan 2019

Finlayson B, Schnick R, Skaar D et al (2010) Planning and standard operating procedures for the use of rotenone in fish management. American Fisheries Society, Bethesda, MD

Forsyth DM, Tustin KG (2001) Advances in New Zealand mammalogy 1990-2000: Himalayan tahr. J R Soc N Z 31:251-261. https://doi.org/10.1080/03014223.2001.9517653

Furman BL, Bewick AJ, Harrison TL et al (2015) Pan-African phylogeography of a model organism, the African clawed frog Xenopus laevis. Mol Ecol 24:909-925. https://doi.org/10. $1111 /$ mec. 13076

Furman B, Cauret C, Colby G et al (2017) Limited genomic consequences of hybridization between two African clawed frogs, Xenopus gilli and X. laevis (Anura: Pipidae). Sci Rep 7:1091. https:// doi.org/10.1038/s41598-017-01104-9

Gaertner M, Larson BMH, Irlich UM et al (2016) Managing invasive species in cities: a framework from Cape Town, South Africa. Landsc Urban Plan 151:1-9. https://doi.org/10.1016/j. landurbplan.2016.03.010

Game ET, Meijaard E, Sheil D et al (2014) Conservation in a wicked complex world; challenges and solutions. Conserv Lett 7:271-277. https://doi.org/10.1111/conl.12050

Gosling M (2002) Friends of the Tahr slam SA National Parks for failing to find a humane solution. Cape Times, 5 July 2002

Greve M, von der Meden CEO, Janion-Scheepers C (2020) Biological invasions in South Africa's offshore sub-Antarctic territories. In: van Wilgen BW, Measey J, Richardson DM et al (eds) Biological invasions in South Africa. Springer, Berlin, pp 205-226. https://doi.org/10.1007/ 978-3-030-32394-3_8

Griffiths CL, Hockey PAR, van Erkom Schurink C et al (1992) Marine invasive aliens on South African shores-implications for community structure and trophic functioning. S Afr J Mar Sci 12, 713-722. https://doi.org/10.2989/02577619209504736

Gumede T, Downs CT (2019) Sugar preference of invasive Common Mynas (Sturnus tristis). J Ornithol 160:71-78. https://doi.org/10.1007/s10336-018-1600-x

Hampton SL, Griffiths CL (2007) Why Carcinus maenas cannot get a grip on South Africa's waveexposed coastline. Afr J Mar Sci 29:123-126. https://doi.org/10.2989/AJMS.2007.29.1.11.76

Hart LA, Downs CT (2014) Public surveys of rose-ringed parakeets, Psittacula krameri, in the Durban Metropolitan area, South Africa. Afr Zool 49:283-289. https://doi.org/10.1080/ 15627020.2014 .11407644

Hart L, Downs C (2015) Winged invaders: bird introductions. Quest 11:38-41

Haupt K (2015) Assessment of the invasive German wasp, Vespula germanica, in South Africa. M. Sc. thesis, Stellenbosch University, Stellenbosch

Haupt TM, Griffiths CL, Robinson TB et al (2010) Oysters as vectors of marine aliens, with notes on four introduced species associated with oyster farming in South Africa. Afr Zool 45:52-62. https://doi.org/10.3377/004.045.0101

Herbert DG, Sirgel WF (2001) The recent introduction of two potentially pestiferous alien snails into South Africa and the outcomes of different pest management practices: an eradication and a colonization. S Afr J Sci 97:301-304 
Hirsch PD, Adams WM, Brosius JP et al (2010) Acknowledging conservation trade-offs and embracing complexity. Conserv Biol 25:259-264. https://doi.org/10.1111/j.1523-1739.2010. 01608.x

Impson ND, Harding B, Steyn G (2005) The use of rotenone as a tool for restructuring fish populations in inland waters of the fynbos biome. Piscator 137:63-69

IUCN SSC Amphibian Specialist Group and South African Frog Re-assessment Group (SA-FRoG) 2017. Xenopus gilli. The IUCN Red List of Threatened Species 2017: e.T23124A77164368. Downloaded on 11 January 2019. https://doi.org/10.2305/IUCN.UK.2017-2.RLTS. T23124A77164368.en

Jackson MC, Gery J, Miller K et al (2016) Dietary niche constriction when invaders meet natives: evidence from freshwater decapods. J Anim Ecol 85:1098-1107. https://doi.org/10.1111/13652656.12533

Janion-Scheepers C, Griffiths CL (2020) Alien terrestrial invertebrates in South Africa. In: van Wilgen BW, Measey J, Richardson DM et al (eds) Biological invasions in South Africa. Springer, Berlin, pp 183-204. https://doi.org/10.1007/978-3-030-32394-3_7

Karsten M, Jansen van Vuuren B, Addison P et al (2015) Deconstructing intercontinental invasion pathway hypotheses of the Mediterranean fruit fly (Ceratitis capitata) using a Bayesian inference approach: are port interceptions and quarantine protocols successfully preventing new invasions? Divers Distrib 21:813-825. https://doi.org/10.1111/ddi.12333

Karsten M, Barton M, Addison P et al (2018) A synthesis for managing invasions and pest risks simultaneously for tephritid fruit flies in South Africa. Entomol Exp Appl 166:344-356. https:// doi.org/10.1111/eea.12664

Kleynhans CJ (1987) A preliminary study of aspects of a rare minnow Barbus treurensis Groenewald, 1958 (Pisces: Cyprinidae) from the Eastern Transvaal, South Africa. J Limnol Soc S Afr 13:7-13. https://doi.org/10.1080/03779688.1987.9634537

Lester PJ, Beggs JR (2019) Invasion success and management strategies for social Vespula wasps. Ann Rev Entomol 64:51-71. https://doi.org/10.1146/annurev-ento-011118-111812

Lloyd PHT (1975) A study of the Homalaayan Tahr (Hemitragus jemlahicus) and its potential effects on the ecology of the Table Mountain range. Cape Department of Nature and Environmental Conservation, Cape Town

Mabin CA, Wilson JRU, Robinson TB (2015) The Chilean black urchin, Tetrapygus niger (Molina, 1782) in South Africa: gone but not forgotten. BioInvasions Rec 4:261-264. https://doi.org/10. 3391/bir.2015.4.4.05

Mabin CA, Wilson JRU, Le Roux JJ, Robinson TB (2017) Reassessing the invasion of South African waters by the European shore-crab Carcinus maenas. Afr J Mar Sci 39:259-267. https://doi.org/10.2989/1814232X.2017.1363818

Manrakhan A, Grout T, Hattingh V (2009) Combating the African invader fly Bactrocera invadens. SA Fruit J 8:57-61

Manrakhan A, Hattingh V, Venter J-H et al (2011) Eradication of Bactrocera invadens (Diptera: Tephritidae) in Limpopo Province, South Africa. Afr Entomol 19:650-659. https://doi.org/10. 4001/003.019.0307

Manrakhan A, Venter J-H, Hattingh V (2012) Action Plan for the Control of the African Invader Fruit Fly, Bactrocera invadens Drew, Tsuruta and White. Department of Agriculture, Forestry and Fisheries, Pretoria

Manrakhan A, Venter J-H, Hattingh V (2015) The progressive invasion of Bactrocera dorsalis (Diptera: Tephritidae) in South Africa. Biol Invasions 17:2803-2809. https://doi.org/10.1007/ s10530-015-0923-2

Marr SM, Impson ND, Tweddle D (2012) An assessment of a proposal to eradicate non-native fish from priority rivers in the Cape Floristic Region, South Africa. Afr J Aquat Sci 37:131-142. https://doi.org/10.2989/16085914.2012.666654

Marr SM, Bellingan TA, Dalu T et al (2019) Rotenone policy support and capacity development: Part 1: impact and recovery of native biota in one river and two dams following alien fish removals using rotenone, WRC project no. K5/2538. Water Research Commission, Pretoria 
Mead A, Carlton JT, Griffiths CL et al (2011a) Introduced and cryptogenic marine and estuarine species of South Africa. J Nat Hist 45:2463-2524. https://doi.org/10.1080/00222933.2011. 595836

Mead A, Carlton JT, Griffiths CL et al (2011b) Revealing the scale of marine bioinvasions in developing regions: a South African re-assessment. Biol Invasions 13:1991-2008. https://doi. org/10.1007/s10530-011-0016-9

Measey J, Dorse S, Faraday A (2012) Conservation of the western leopard toad by a dedicated multi-stakeholder group in the City of Cape Town. FrogLog 103:14-16

Measey GJ, Annecke W, Davies SJ, Dorse C, Stafford L, Tolley KA, Turner AA (2014) Cape collaborations for amphibian solutions. FrogLog 109:46-47

Measey J, Davies SJ, Vimercati G et al (2017) Invasive amphibians in southern Africa: a review of invasion pathways. Bothalia 47:a2117. https://doi.org/10.4102/abc.v47i2.2117

Measey J, Hui C, Somers MJ (2020) Terrestrial vertebrate invasions in South Africa. In: van Wilgen BW, Measey J, Richardson DM et al (eds) Biological invasions in South Africa. Springer, Berlin, pp 113-150. https://doi.org/10.1007/978-3-030-32394-3_5

Mwatawala MW, White IM, Maerere AP et al (2004) A new invasive Bactrocera species (Diptera: Tephritidae) in Tanzania: short communication. Afr Entomol 12:154

Novoa A, Shackleton R, Canavan S et al (2018) A framework for engaging stakeholders on the management of alien species. J Environ Manag 205:286-297. https://doi.org/10.1016/j. jenvman.2017.09.059

Nunes AL, Hoffman AC, Zengeya TA et al (2017) Red swamp crayfish, Procambarus clarkii, found in South Africa 22 years after attempted eradication. Aquat Conserv Mar Freshwat Ecosyst 27:1334-1340. https://doi.org/10.1002/aqc.2741

Picker MD, Griffiths CL (2017) Alien animals in South Africa-composition, introduction history, origins and distribution patterns. Bothalia 47:2311-9284. https://doi.org/10.4102/abc.v47i2. 2147

Picker MD, De Villiers AL (1989) The distribution and conservation status of Xenopus gilli (Anura: Pipidae). Biol Conserv 49:169-183. https://doi.org/10.1016/0006-3207(89)90034-7

Picker MD, Harrison JA, Wallace D (1996) 4. Natural hybridization between Xenopus laevis laevis and X. gilli in the south-western Cape Province, South Africa. In: Tinsley RC, Kobel HR (eds) The biology of Xenopus. Oxford University Press, London, pp 1960-1999

Potgieter L, Douwes E, Gaertner M et al (2020) Biological invasions in South Africa's urban ecosystems: patterns, processes, impacts and management. In: van Wilgen BW, Measey J, Richardson DM et al (eds) Biological invasions in South Africa. Springer, Berlin, pp 273-310. https://doi.org/10.1007/978-3-030-32394-3_11

Richardson DM, Pyšek P, Carlton JT (2011) A compendium of essential concepts and terminology in invasion ecology. In: Richardson DM (ed) Fifty years of invasion ecology. The legacy of Charles Elton. Wiley-Blackwell, Oxford, pp 409-420. https://doi.org/10.1002/9781444329988. $\operatorname{ch} 30$

Robben Island Museum (2016) Natural environmental policy. Department of Arts and Culture, Cape Town

Robinson TB, Peters K, Brooker B (2020) Coastal invasions: the South African context. In: van Wilgen BW, Measey J, Richardson DM et al (eds) Biological invasions in South Africa. Springer, Berlin, pp 227-246. https://doi.org/10.1007/978-3-030-32394-3_9

RSA (Republic of South Africa) (2014) National environment management: biodiversity act, 2004 (Act no. 10 of 2004). Alien and Invasive Species Regulations. Government Gazette No. 37886

RSA (Republic of South Africa) (2016) National environmental management: biodiversity act, 2004 (Act no. 10 of 2004); Alien and Invasive Species Lists. Government Notice R864, Government Gazette No. 40166

Scarlett L, McKinney M (2016) Connecting people and places: the emerging role of network governance in large landscape conservation. Front Ecol Environ 14:116-125. https://doi.org/10. $1002 /$ fee. 1247

Schutze MK, Aketarawong N, Amornsak W et al (2015) Synonymization of key pest species within the Bactrocera dorsalis species complex (Diptera: Tephritidae): taxonomic changes based on a 
review of 20 years of integrative morphological, molecular, cytogenetic, behavioural and chemoecological data. Syst Entomol 40:456-471. https://doi.org/10.1111/syen.12113

Shelton JM, Samways MJ, Day JA (2014) Predatory impact of non-native rainbow trout on endemic fish populations in headwater streams in the Cape Floristic Region of South Africa. Biol Invasions 17:365-379. https://doi.org/10.1007/s10530-014-0735-9

Shelton J, Weyl O, van der Walt J et al (2017) Effect of an intensive mechanical removal effort on a population of non-native rainbow trout Oncorhynchus mykiss in a South African headwater stream. Aquat Conserv Mar Freshwat Ecosyst 27:1-5. https://doi.org/10.1002/aqc.2752

Simakani S (2017) "BEEWARE of the wasp": the role of language in studying and managing the European Paper Wasp. M.A. thesis, Stellenbosch University, Stellenbosch

Skead CJ, Boshoff A, Kerley GIH et al (2011) Introduced (non-indigenous) species: a growing threat to biodiversity. In: Skead CJ, Boshoff A, Kerley GIH, Lloyd P (eds) Historical incidence of the larger land mammals in the broader Northern and Western Cape, vol 1. Centre for African Conservation Ecology, Nelson Mandela Metropolitan University, Port Elizabeth

Skelton PH (2001) A complete guide to the freshwater fishes of Southern Africa. Struik Publishers, Cape Town

Skelton PH (1993) On bass in Blindekloof-the impact of an alien predator on a wilderness stream. Naturalist 37:21-27

Stephens K, Measey J, Reynolds C et al (2020) Occurrence and extent of hybridization between the invasive Mallard Duck and native Yellow-billed Duck in South Africa. Biol Invasions 22:693707. https://doi.org/10.1007/s10530-019-02122-6

Suckling DM, Kean JM, Stringer LD et al (2014) Eradication of tephritid fruit fly pest populations: outcomes and prospects. Pest Manag Sci 72:456-465. https://doi.org/10.1002/ps.3905

Suliman AS, Meier GG, Haverson PJ (2011) Eradication of the house crow from Socotra Island, Yemen. In: Veitch CR, Clout MN, Towns DR (eds) Island invasives: eradication and management. IUCN, Gland, pp 361-363

Telford N, Channing A, Measey J (2019) Origin of invasive populations of the Guttural toad Sclerophrys gutturalis. Herpetol Conserv Biol 14(2):380-392

Thorp CJ, Vonesh JR, Measey J (2019) Cannibalism or congeneric predation? The African clawed frog (Xenopus laevis Daudin) preferentially predate on larvae of Cape platannas, X. gilli Rose and Hewitt. Afr J Ecol 57:59-65. https://doi.org/10.1111/aje.12577

Tribe GD, Richardson DM (1994) The European wasp, Vespula germanica (Fabricius) (Hymeoptera, Vespidae), in southern Africa and its potential distribution as predicted by ecoclimatic matching. Afr Entomol 2:1-6

van der Walt JA, Weyl OLF, Woodford DJ et al (2016) Spatial extent and consequences of black bass (Micropterus spp.) invasion in a Cape Floristic Region river basin. Aquat Conser Mar Freshwat Ecosyst 26:736-748. https://doi.org/10.1002/aqc.2589

van der Walt JA, Marr SM et al (2018) Successful mechanical eradication of spotted bass (Micropterus punctulatus (Rafinesque, 1819)) from a South African river. Aquat Conser Mar Freshwat Ecosyst. https://doi.org/10.1002/aqc.3035

van Rensburg BJ, Weyl OLF, Davies SJ et al (2011) Invasive vertebrates of South Africa. In: Pimentel D (ed) Biological invasions: economic and environmental costs of alien plant, animal, and microbe species, 2nd edn. CRC Press, Boca Raton, pp 325-378. https://doi.org/10.1201/ b10938-23

van Wilgen BW, Wilson JR (eds) (2018) The status of biological invasions and their management in South Africa in 2017. South African National Biodiversity Institute, Kirstenbosch and DST-NRF Centre of Excellence for Invasion Biology, Stellenbosch

van Wilgen BW, Measey J, Richardson DM et al (2020) Biological invasions in South Africa: an overview. In: van Wilgen BW, Measey J, Richardson DM et al (eds) Biological invasions in South Africa. Springer, Berlin, pp 3-30. https://doi.org/10.1007/978-3-030-32394-3_1

van Zyl C, Addison P, Veldtman R (2018) The invasive Vespidae in South Africa: potential management strategies and current status. Afr Entomol 26:267-285. https://doi.org/10.4001/ 003.026.0267 
Veldtman R, Addison P, Tribe GD (2012) Current status and potential future impact of invasive vespid wasps (Vespula germanica and Polistes dominulus) in South Africa. IOBC/WPRS Bull $75: 217-221$

Viljoen JH (1990) The occurrence of Trogoderma (Coleoptera: Dermestidae) and related species in Southern Africa with special reference to $T$. granarium and its potential to become established. J Stored Prod Res 26:43-51. https://doi.org/10.1016/0022-474X(90)90036-R

Vimercati G, Hui C, Davies SJ et al (2017a) Integrating age structured and landscape resistance models to disentangle invasion dynamics of a pond-breeding anuran. Ecol Model 356:104-116. https://doi.org/10.1016/j.ecolmodel.2017.03.017

Vimercati G, Davies SJ, Hui C et al (2017b) Does restricted access limit management of invasive urban frogs? Biol Invasions 19:3659-3674. https://doi.org/10.1007/s10530-17-1599-6

Vogt S, De Villiers FA, Ihlow F et al (2017) Competition and feeding ecology in two sympatric Xenopus species (Anura: Pipidae). PeerJ 5:e3130. https://doi.org/10.7717/peerj.3130

Weyl OLF, Finlayson B, Impson ND et al (2014) Threatened endemic fishes in South Africa's Cape Floristic Region: a new beginning for the Rondegat River. Fisheries 39:270-279. https://doi. org/10.1080/03632415.2014.914924

Weyl OLF, Ellender BR, Wasserman RJ et al (2015) Unintended consequences of using alien fish for human benefit in protected areas Koedoe 57, Art. \#1264, 5 p. https://doi.org/10.4102/ koedoe.v57i1.1264

Weyl OLF, Ellender B, Wassermann RJ et al (2020) Alien freshwater fauna in South Africa. In: van Wilgen BW, Measey J, Richardson DM et al (eds) Biological invasions in South Africa. Springer, Berlin, pp 151-182. https://doi.org/10.1007/978-3-030-32394-3_6

Woodford DJ, Barber-James HM, Bellingan TA et al (2013) Immediate impact of piscicide operations on a Cape Floristic Region aquatic insect assemblage: a lesser of two evils? J Insect Conserv 17:959-973. https://doi.org/10.1007/s10841-013-9578-4

Woodford DJ, Richardson DM, MacIsaac HJ et al (2016) Confronting the wicked problem of managing invasive species. Neobiota 31:63-86. https://doi.org/10.3897/neobiota.31.10038

Woodford DJ, Ivey P, Jordaan MS et al (2017) Optimising invasive fish management in the context of invasive species legislation in South Africa. Bothalia 47:a2138. https://doi.org/10.4102/abc. v47i2.2138

Younge A, Fowkes S (2003) The Cape Action Plan for the Environment: overview of an ecoregional planning process. Biol Conserv 112:15-28

Zengeya T, Ivey P, Woodford DJ et al (2017) Managing conflict-generating invasive species in South Africa: challenges and trade-offs. Bothalia 47:a2160. https://doi.org/10.4102/abc.v47i2. 2160

Open Access This chapter is licensed under the terms of the Creative Commons Attribution 4.0 International License (http://creativecommons.org/licenses/by/4.0/), which permits use, sharing, adaptation, distribution and reproduction in any medium or format, as long as you give appropriate credit to the original author(s) and the source, provide a link to the Creative Commons licence and indicate if changes were made.

The images or other third party material in this chapter are included in the chapter's Creative Commons licence, unless indicated otherwise in a credit line to the material. If material is not included in the chapter's Creative Commons licence and your intended use is not permitted by statutory regulation or exceeds the permitted use, you will need to obtain permission directly from the copyright holder.

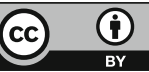

